\title{
Vegetative Propagation Trial of Prosopis africana (Guill. et Perr.) Taub. by Air Layering under Sudano-Sahelian Climate in the South-Central Niger
}

\author{
Laouali Abdou, ${ }^{1}$ Saley Karim, ${ }^{1}$ Rabiou Habou, ${ }^{1}$ and Ali Mahamane ${ }^{2}$ \\ ${ }^{1}$ Département de Biologie, Faculté des Sciences et Techniques, Université Dan Dicko Dankoulodo de Maradi, BP 465, Maradi, Niger \\ ${ }^{2}$ Laboratoire Garba Mounkaila, Département de Biologie, Faculté des Sciences, Université Abdou Moumouni, BP 10662, Niamey, Niger \\ Correspondence should be addressed to Laouali Abdou; abdoulaouali2000@yahoo.fr
}

Received 11 July 2015; Accepted 7 September 2015

Academic Editor: An Vanden Broeck

Copyright (C) 2015 Laouali Abdou et al. This is an open access article distributed under the Creative Commons Attribution License, which permits unrestricted use, distribution, and reproduction in any medium, provided the original work is properly cited.

Prosopis africana is a species of great socioeconomic importance but threatened with extinction in Niger because of overuse and regeneration problem. This study, conducted in the Maradi (Niger) area, precisely at El Gueza in the south of Gazaoua department, aims to evaluate the vegetative propagation capacity of $P$. africana by air layering under the Sudano-Sahelian climate of the southcentral Niger. A ring of bark was taken on each selected branch and the wound was covered with a black plastic filled with a damp mixture of soil and wood debris. The chosen parameters are the diameter class and the position on the branch. In all, 60 branches were treated and followed for 130 days: $28.33 \%$ produced shoots and there was no significant difference between the diameter classes and between the positions. These results show that propagating trees of the species by air layering is possible and this technique can be used to multiply and keep this species, which will reduce the regeneration problem linked to a low seed germination rate.

\section{Introduction}

Woody plants have played, for centuries, an important socioeconomic role for rural populations in West Africa in general and in Niger in particular [1-4]. Most species playing this socioeconomic role are subject to high anthropogenic pressure reducing their natural regeneration. Many populations of woody species are thus in a regressive dynamic characterized by scarcity or absence of young individuals [5-7]. The exploitation and marketing of nontimber forest products in Africa to date are primarily designed to increase individual incomes of gatherers without concern for sustainable management, which would require taking into account the regeneration patterns of the species involved and promoting their domestication in order to reduce the pressure on their natural populations [8]. Many tropical species with nutritive or market have a little known way of natural regeneration [6]. Wood plant reproduction by seed is the most common mode of natural regeneration [9]. However, for some species, lack of seeds or low germination capacity reduces the production of seedlings in nurseries [10]. In such cases, vegetative propagation can be an advantageous alternative $[9,11]$ by offering the opportunity to rapidly overcome the limitations to domestication imposed by long generation times, irregular fruiting/flowering, and outbreeding [12].

Prosopis africana is a species with domestic uses that are of inestimable importance [13-20]. Its natural distribution is from Senegal to Ethiopia to the north, Guinea to Cameroon to the south, and Uganda to Egypt to the east [21] but it is threatened with extinction in Niger. The leaves and pods are used by farmers for animal food, and the bark and roots are used to treat diseases. Its wood is very resistant to decay and is used to make household tools (mortars and pestles), charcoal, which is highly appreciated by blacksmiths, and poles for construction $[15,20]$. At the same time, this species is facing a regeneration problem mainly due to a low germination rate [22-26] because of the hardness of the seed [27] and a low fruit production [28-30].

To date, there is not much information on the vegetative propagation of $P$. africana using the air layering technique, 


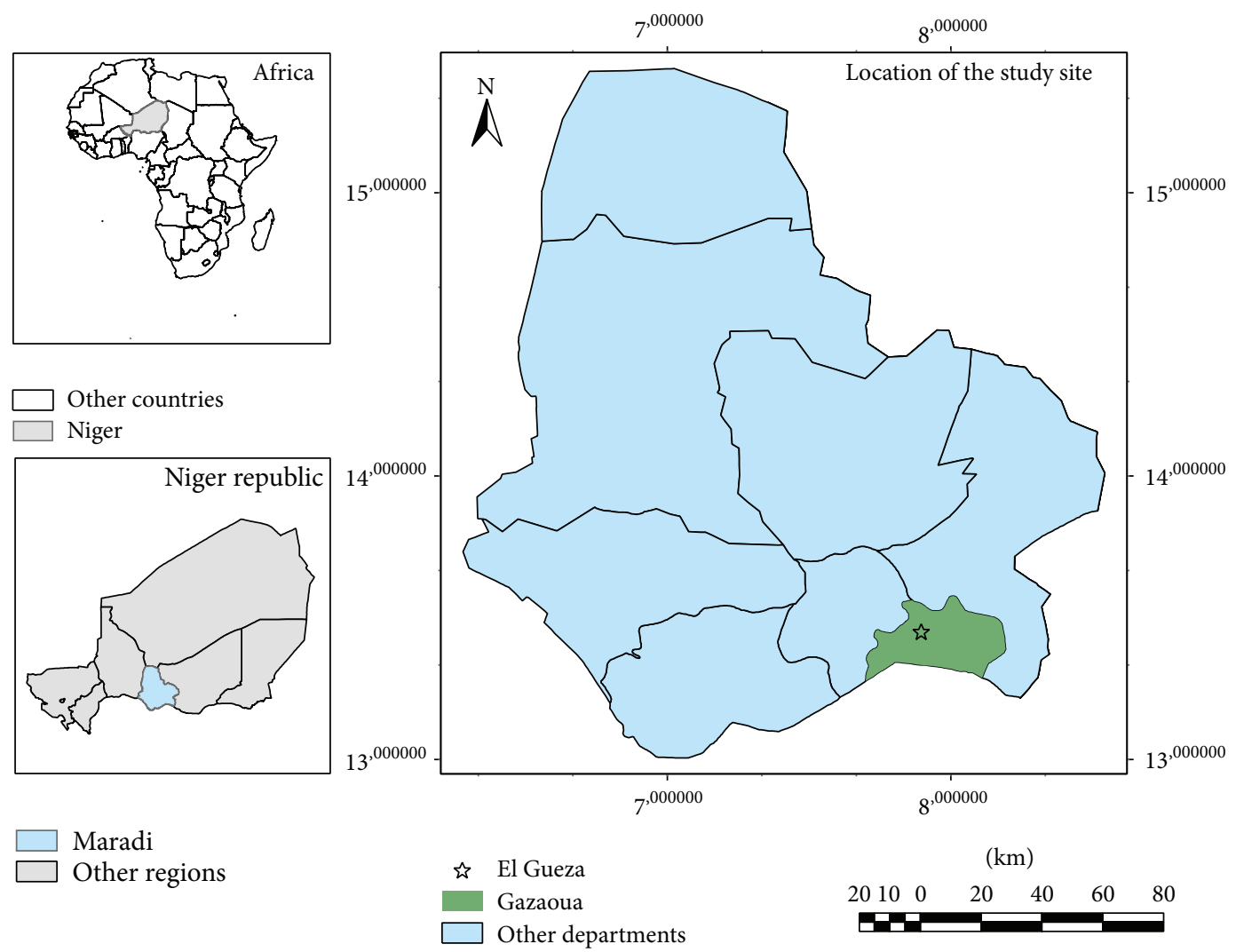

FIGURE 1: Location of the study site.

especially in the Niger climatic context. The germination difficulties and lack of knowledge about vegetative propagation techniques of $P$. africana are a serious obstacle to the conservation of the species, given the human pressures and climatic hazards. It is then indispensable to have information of the vegetative propagation of the species to facilitate its regeneration in southern Niger where it still exists, especially to the state of isolated individuals.

The main objective of this study is to evaluate the vegetative propagation capacity by air layering of $P$. africana under the Sahel-Sudanese climate of southern Niger.

\section{Materials and Methods}

2.1. Study Site. This study was conducted in the village territory of El Gueza in the Gazaoua department, located in the southern part of the Maradi region (Figure 1). The socioeconomic activities of the local population are dominated by agriculture, livestock, crafts, and trade. The climate is of Sahelo-Sudanian type and the average annual temperature is $28^{\circ} \mathrm{C}$. The average annual rainfall from 1981 to 2010 at the Gazaoua station (nearest the site) is $446.32 \mathrm{~mm} \pm 117.95$. The soils are mainly dunal and the flora is dominated by Mimosaceae (Prosopis africana, Albizia chevalieri, and Faidherbia albida), Caesalpiniaceae (Piliostigma reticulatum, Cassia singueana, and Bauhinia rufescens), Combretaceae (Combretum glutinosum, Guiera senegalensis, and Anogeissus leiocarpa), and Anacardiaceae (Sclerocarya birrea and Lannea microcarpa). The vegetation consists of Combretum thickets, steppes, low dry forests, gallery forests, and savannas [31]. The choice of this site is based on the presence of $P$. africana which is one of the main species of agroforestry parklands in the area.

2.2. Setting Up the Marcots. Air layering was chosen for this study because it is an excellent method to multiply trees of various species and can be practiced on almost all woody plants $[32,33]$. The parameters are the class diameter and position of the layering on the branch. Two diameter classes were used: one class was for branches $1-2 \mathrm{~cm}$ in diameter and the other class was for branches $2-3 \mathrm{~cm}$ in diameter. Positions were the middle part and the basal part of the branch. A total of 60 marcots were distributed on 15 trees. On each tree, four marcots were placed as follows:

(i) Two marcots in the class $1-2 \mathrm{~cm}$ : one on the middle part and the other on the basal part.

(ii) Two marcots in the class $2-3 \mathrm{~cm}$ : one on the middle part and the other on the basal part.

In total, the marcots are therefore distributed as follows:

(i) 30 marcots in the class $1-2 \mathrm{~cm}$ : 15 are on the middle part and 15 on the basal part.

(ii) 30 marcots in the class $2-3 \mathrm{~cm}$ : 15 are on the middle part and 15 on the basal part. 


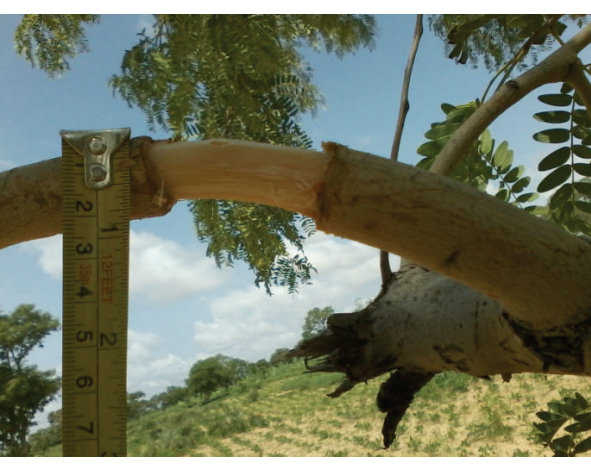

(a)

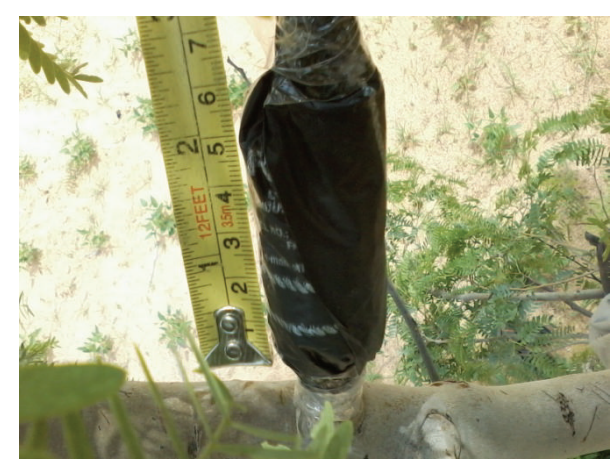

(b)

FIGURE 2: Induction of layering (girdling on the left and setting up the sleeve containing the substrate on the right).

The marcots were placed on August 17 and August 18, 2013, and the harvest took place December 28, 2013, 130 days after the establishment. A ring of bark, $3 \mathrm{~cm}$ long, was removed from the selected branches. The girdled surface was covered with black plastic filled with a substrate composed of $2 / 3$ glumes of millet (Pennisetum glaucum) mixed with debris from the manufacture of mortars and pestles which is like sawdust $[9,34]$ and $1 / 3$ of soil from under the crown of the concerned feet (Figure 2). This substrate, accessible and available in the field, is used here to replace Sphagnum [35-38] or foam [11], which has been lacking. It is also a lightweight substrate, porous enough to promote good circulation of oxygen, with good water retention capacity as high humidity in the substrate is essential for the success of air layering $[32,39]$. Using a syringe, water was injected into the mixture every 2 weeks, starting in mid-September with decreasing frequency of rainfall and the return of heat. The number and quality of the newly formed adventitious roots were retained as evaluation criteria for the success of the layering. A caretaker was appointed to monitor the marcots.

2.3. Data Analysis. The marcots that issued roots were classified by diameter and position. For each of these marcots, the roots were counted. An analysis of variance was performed with the Minitab 16 software to compare the proportions of presence of roots and the average number of roots between the two classes of diameter and between the two positions.

\section{Results}

After this study, 17 of the 60 marcots gave roots, a success rate of $28.33 \%$ (Table 1). On the 30 marcots of each of two diameter classes, 11 gave roots for the class $1-2 \mathrm{~cm}$, or $36.66 \%$, and six for the class 2-3, or $20 \%$. On the 30 marcots of each of two positions, 10 gave roots to the middle position, or $33.33 \%$, and seven to the basal position, or $23.33 \%$. Comparing the proportions of successful marcots revealed no significant difference between the two diameter classes $(P=0.145)$ or between two positions $(P=0.387)$.

The average number of roots by diameter class and position is reported in Table 2. The analysis of variance showed that there was no statistically significant difference
TABLE 1: Number of marcots giving roots according to the diameter and position.

\begin{tabular}{lccc}
\hline Position & \multicolumn{3}{c}{ Diameter $(\mathrm{cm})$} \\
& $1-2$ & $2-3$ & Total \\
\hline Middle & 6 & 4 & 10 \\
Basal & 5 & 2 & 7 \\
Total & 11 & 6 & 17 \\
\hline
\end{tabular}

TABLE 2: Average number of roots by diameter class and position.

\begin{tabular}{lccc}
\hline \multicolumn{2}{c}{ Diameter class $(\mathrm{cm})$} & \multicolumn{2}{c}{ Position } \\
\hline $1-2$ & $2-3$ & Middle & Basal \\
$1.91 \pm 1,30$ & $2.167 \pm 0.983$ & $1.900 \pm 0,994$ & $2.14 \pm 1.46$ \\
\hline
\end{tabular}

in the number of roots between the two diameter classes $(P=0.679)$ and two positions $(P=0.688)$.

Most of the roots obtained were very small and some marcots showed signs of dehydration (Figure 3).

\section{Discussion}

Vegetative propagation of plants is essentially the reproduction of plant material from vegetative organs so that the offspring will contain the exact characteristics of the parent plant with regard to genotypes and health status [40]. Air layering is the technique that has been widely used in the domestication of indigenous fruit trees in west and central Africa in capturing the attributes of elite trees within genetically diverse wild populations, so it avoids the long, slow process of tree breeding [9] and promotes a high success rate because it prevents the water stress and carbohydrate shortage that plague cuttings [38]. With a success rate of $28.33 \%$ in this study, the ability of $P$. africana to multiply by air layering is low. These results corroborate those found by the author in [36] who observed a low success rate for this species compared to Detarium microcarpum Guill. \& Perr. Several trials of air layering have however given more satisfactory results on other species: Pterocarpus erinaceus Poir. with 100\% success in Burkina Faso [37], Balanites 


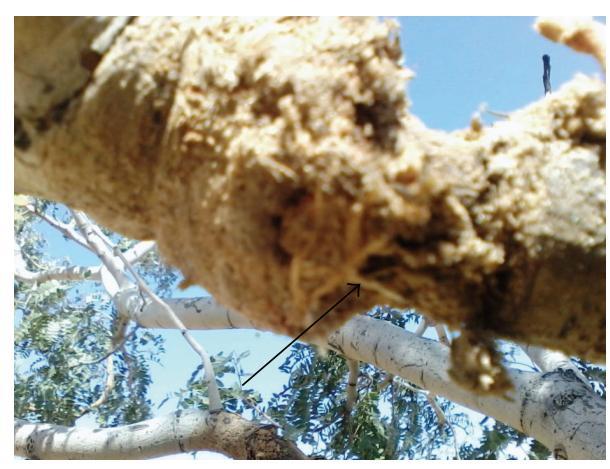

Figure 3: A marcot with some roots.

aegyptiaca (L.) Del. with a success rate of $95 \%$ in Cameroon [41], Coula edulis Baill. with 48\% success in Gabon [11], and Prunus azorica (Hort. ex Mouillef.) Rivas Mart. with $100 \%$ success in Azores [42]. The success of these trials may be linked to conditions in which they were carried out, including climatic and methodological. Indeed, the climate in which they were made is wetter. For many authors, a high level of moisture in the substrate is essential for the success of air layering $[32,39]$. In the Sahelian-Sudanian climate, success of layering depends on the plant species and the experimental conditions such as the air humidity and the ambient temperature [39]. In our case, the two-week interval chosen for the supply of water was perhaps too long. In addition, the duration of the experiment (4 months) was perhaps too short because 11 months were necessary to get $48 \%$ success rate for Coula edulis Baill. in Gabon [11]. The auxin (IBA) application could also improve the success rate $[35,43]$ but no auxin was used in this study. The use of a nontransparent plastic is also another handicap because it was impossible for us to observe the evolution inside the marcot during the experiment. The period of implementation could also have an influence because, according to several authors $[9,33,43,44]$, it would have a significant effect on rooting for some species. According to Meunier et al. [45], air layering is more likely to be successful when performed on young branches, although some authors $[46,47]$ found more significant results on branches of 3 to $5 \mathrm{~cm}$ in diameter than on the branches with smaller diameter.

In conclusion, these results show that the propagation of P. africana by air layering is possible even if the success rate is low compared to that of several woody species. We can, in fact, use this technique to multiply and conserve the species and thus reduce the seed germination problem. Selected trees, having a number of potentially interesting characteristics, can be particularly propagated. To improve root production of marcots, further research should include additional parameters, including substrate type, amount of water injected into the marcots, period for setting the marcots, position of the branch in the crown, different provenances, and different trees within provenance. There is considerable genetic variation in tree growth rate and survival among provenances, and provenances from drier locations in Niger are better adapted to drier sites, presumably because they have deeper and more extensive root systems [21, 48], so rooting success of marcots may also vary genetically among provenances. Marcots transplantation to assess their survival rate is also needed and other vegetative propagation techniques, such as cutting and suckering, must also be considered.

\section{Conflict of Interests}

The authors declare that there is no conflict of interests regarding the publication of this paper.

\section{References}

[1] M. Matthias, T. Henri, and H. Félix, "Ligneux à usages multiples dans les systèmes agraires tropicaux: une étude de cas de Côte d'Ivoire," Schweizerische Zeitschrift für Forstwesen, vol. 151, no. 10, pp. 355-364, 2000.

[2] M. Diop, B. Kaya, A. Niang, and A. Olivier, "Les espèces ligneuses et leurs usages: les préférences des paysans dans le Cercle de Ségou, au Mali," ICRAF Working Paper 9, World Agroforestry Centre, Nairobi, Kenya, 2005.

[3] M. Larwanou, I. Oumarou, L. Snook, I. Dan Guimbo, and O. Eyog-Matig, "Pratiques sylvicoles et culturales dans les parcs agroforestiers suivant un gradient pluviométrique nord-sud dans la région de Maradi au Niger," Tropicultura, vol. 28, no. 2, pp. 115-122, 2010.

[4] R. J. Priso, J. F. Nnanga, J. Etame, N. Din, and A. Amougou, "Les produits forestiers non ligneux d'origine végétale: valeur et importance dans quelques marchés de la région du LittoralCameroun," Journal of Applied Biosciences, vol. 40, pp. 27152726, 2011.

[5] B. A. Endress, D. L. Gorchov, and E. J. Berry, "Sustainability of a non-timber forest product: effects of alternative leaf harvest practices over 6 years on yield and demography of the palm Chamaedorea radicalis," Forest Ecology and Management, vol. 234, no. 1-3, pp. 181-191, 2006.

[6] R. Bellefontaine, A. Ferradous, M. Alifriqui, and O. Monteuuis, "Multiplication végétative de l'arganier, Argania spinosa, au Maroc: le projet John Goelet," Bois et Forêts des Tropiques, vol. 304, no. 2, pp. 47-59, 2010.

[7] S. Sanogo, M. Sacandé, P. Van Damme, and I. N’Diaye, “Caractérisation, germination et conservation des graines de Carapa procera DC. (Meliaceae), une espèce utile en santé humaine et animale," Biotechnologie, Agronomie, Société et Environnement, vol. 17, no. 2, pp. 321-331, 2013.

[8] A. Ouédraogo, A. Thiombiano, K. Hahn-Hadjali, and S. Guinko, "Régénération sexuée de Boswellia dalzielii Hutch., un arbre médicinal de grande valeur au Burkina-Faso," Bois et forêts des Tropiques, vol. 289, no. 3, pp. 41-52, 2006.

[9] Z. Tchoundjeu, E. Asaah, and A. Atangana, "Methods for vegetative propagation: theory. Lecture handout for SII training workshop on Allanblackia domestication," Tech. Rep. ICRAFWCA/HT, ICRAF, Nairobi, Kenya, 2006.

[10] Z. Tchoundjeu, M.-L. N. Mpeck, E. Asaah, and A. Amougou, "The role of vegetative propagation in the domestication of Pausinystalia johimbe (K. Schum), a highly threatened medicinal species of West and Central Africa," Forest Ecology and Management, vol. 188, no. 1-3, pp. 175-183, 2004.

[11] C. Moupela, J. L. Doucet, K. Daïnou, Q. Meunier, C. Vermeulen, and J. Beauchêne, "Essais de propagation par semis et marcottage aérien de Coula edulis Baill. et perspectives pour sa 
domestication," Bois et Forêts des Tropiques, vol. 318, no. 4, pp. 3-13, 2013.

[12] R. R. B. Leakey, A. C. Newton, and J. M. Dick, "Capture of genetic variation by vegetative propagation: processes determining success," in Tropical Trees: The Potential for Domestication and the Rebuilding of Forest Resources, R. R. B. Leakey and A. C. Newton, Eds., ITE Symposium 29, pp. 72-83, HMSO, London, UK, 1994.

[13] H. J. V. Maydell, Arbres et arbustes du Sahel. Leurs caractéristiques et leurs utilisations, G.T.Z., Schriftenreihe, Eschborn, Germany, 1983.

[14] L. Mahamane, Potentials of Prosopis africana (G. et Perr.) Taub leaf litter for soil nutrient enhancement and crop development [M.S. thesis], Department of Forest resources Management, University of Ibadan, 1994.

[15] Z. Tchoundjeu, J. Weber, and L. Guarino, "Germplasm collections of endangered agroforestry tree species: the case of Prosopis africana in the semi-arid lowlands of West Africa," Agroforestry Systems, vol. 39, no. 1, pp. 91-100, 1997.

[16] B. O. Omafuvbe, S. H. Abiose, and O. O. Adaraloye, "The production of 'Kpaye'-a fermented condiment from Prosopis africana (Guill and Perr) Taub. Seeds," International Journal of Food Microbiology, vol. 51, no. 2-3, pp. 183-186, 1999.

[17] M. Arbonnier, Arbres, arbustes et lianes des zones sèches d'Afrique de l'Ouest, CIRAD, MNHN, UICN, Montpellier, France, 2000.

[18] D. A. Agboola, "Prosopis africana (Mimosaceae): stem, roots, and seeds in the economy of the savanna areas of Nigeria," Economic Botany, vol. 58, pp. S34-S42, 2004.

[19] M. A. Balogun, A fermentation study and physicochemical analysis of Prosopis africana seeds to produce "OKPEHE", a local condiment [Ph.D. thesis], Department of Microbiology, Faculty of Science, University of Ilorin, Ilorin, Nigeria, 2012.

[20] A. Laouali, I. Dan Guimbo, M. Larwanou, M. M. Inoussa, and A. Mahamane, "Utilisation de Prosopis africana (G. et Perr.) Taub. dans le sud du département d’Aguié au Niger: les différentes formes et leur importance," International Journal of Biological and Chemical Sciences, vol. 8, no. 3, pp. 1065-1074, 2014.

[21] J. C. Weber, M. Larwanou, T. A. Abasse, and A. Kalinganire, "Growth and survival of Prosopis africana provenances tested in Niger and related to rainfall gradients in the West African Sahel," Forest Ecology and Management, vol. 256, no. 4, pp. 585$592,2008$.

[22] A. Akinnagbe and O. Oni, "Quantitative variations in the growth of progeny seedlings of Prosopis africana (Guill., Perrott. and Rich.) plus trees in Nigeria," African Journal of Biotechnology, vol. 6, no. 4, pp. 359-363, 2007.

[23] A. A. Ajiboye, M. O. Atayese, and D. A. Agboola, "Effect of presowing treatments on seed germination and percentage starch content levels in Tamarindus indica, prosopis africana, parkia biglobossa and Albizia lebbeck," Journal of Applied Sciences Research, vol. 5, no. 10, pp. 1515-1519, 2009.

[24] L. E. Ahoton, J. B. Adjakpa, M. M. Ifonti, and L. E. Akpo, "Effet des prétraitements des semences sur la germination de Prosopis africana (Guill., Perrot. Et Rich.) Taub., (Césalpiniacées)," Tropicultura, vol. 27, no. 4, pp. 233-238, 2009.

[25] F. Niang-Diop, B. Sambou, and A. M. Lykke, "Contraintes de régénération naturelle de Prosopis africana: facteurs affectant la germination des graines," International Journal of Biological and Chemical Sciences, vol. 4, no. 5, pp. 1693-1705, 2010.

[26] A. Laouali, I. Dan Guimbo, A. Youchaou, H. Rabiou, and A. Mahamane, "Etude de la germination de la graine et suivi de la croissance en pépinière de Prosopis africana (G. et Perr.) Taub., espèce menacée de disparition au Niger," Annales de l'Université Abdou Moumouni de Niamey, In press.

[27] D. I. Akaaimo and A. O. Raji, "Some physical and engineering properties of Prosopis africana seed," Biosystems Engineering, vol. 95, no. 2, pp. 197-205, 2006.

[28] Y. J. Adigun and A. F. Alonge, "Some engineering properties of Prosopis africana pods relevant to dehulling," Nigerian Journal of Technology, vol. 19, no. 1, pp. 52-58, 2000.

[29] M. Larwanou, Y. Yemshaw, and M. Saadou, "Prediction models for estimating foliar and fruit dry biomasses of five Savannah tree species in the West African Sahel," International Journal of Biological and Chemical Sciences, vol. 4, no. 6, pp. 2245-2256, 2011.

[30] A. Laouali, I. Dan Guimbo, I. Chaibou, and A. Mahamane, "Fruit production of Prosopis africana (G. et Perr.) Taub., an overexploited species in the Southeastern Niger," International Journal of Current Microbiology and Applied Sciences, vol. 4, no. 5, pp. 50-56, 2015.

[31] M. Saadou, La végétation des milieux drainés nigériens à l'Est du fleuve Niger [Ph.D. thesis], Université de Niamey, 1990.

[32] H. Jaenicke and J. Beniest, Vegetative Tree Propagation in Agroforestry, Training Guidelines and References, International Centre for Reseach in Agroforestry (ICRAF), 2002.

[33] R. Bellefontaine, "De la domestication à l’amélioration variétale de l'arganier (Argania spinosa L. Skeels)?" Sécheresse, vol. 21, no. 1, pp. 42-53, 2010.

[34] A. W. Zida, Etude de la Régénération de Balanites aegyptiaca (L.) Del., Sclerocarya birrea (A. Rich.) Hochst., et de Diospyros mespiliformis Hochst. ex A. Rich, Mémoire Ingénieur, Université Polytechnique de Bobo Dioulasso, Houet, Burkina Faso, 2009.

[35] E. B. Brennan and K. W. Mudge, "Vegetative propagation of Inga feuillei from shoot cuttings and air layering," New Forests, vol. 15, no. 1, pp. 37-51, 1998.

[36] T. Ricez, Etudes des modes de régénération à faible coût de Prosopis africana et Detarium microcarpum en forêt classée de Dinderesso [Master II: Bioressources en Régions Tropicales et Méditerranéennes], Université Paris Xli Val-de-Marne, Paris, France, 2008.

[37] A. Zouggari, Etat de la régénération et domestication des espèces ligneuses utilisées dans l'artisanat d'art dans l'ouest et le sud-ouest du Burkina Faso [Master II: Bioressources en Régions Tropicales et Méditerranéennes], Paris 12 Val de Marne University, Paris, France, 2008.

[38] R. Diane and B. Elizabeth, Propagation by Cuttings, Layering and Division, College of Agriculture and Life Sciences, Virginia Polytechnic Institute and State University, Blacksburg, Va, USA, 2009.

[39] A. Hammasselbé, "La multiplication végétative du goyavier (Psidium guayava L.) sous climat soudano sahélien du Nord Cameroun," Tropicultura, vol. 23, no. 2, pp. 105-109, 2005.

[40] B. Macdonald, Practical Woody Plant Propagation for Nursery Growers. Volume 1, Timber Press Inc, 1996.

[41] J.-B. N. Tchiagam, J.-P. Ndzié, R. Bellefontaine, and P.-M. Mapongmetsem, "Vegetative propagation of Balanites aegyptiaca (L.) Del., Diospyros mespiliformis Hochst. ex. A. Rich. and Sclerocarya birrea (A. Rich.) Hochst. in northern Cameroon," Fruits, vol. 66, no. 5, pp. 327-341, 2011.

[42] O. Moreira, J. Martins, L. Silva, and M. Moura, "Propagation of the endangered Azorean cherry Prunus azorica using stem 
cuttings and air layering," Arquipélago. Life and Marine Sciences, vol. 26, pp. 9-14, 2009.

[43] Z. Tchoundjeu, M. L. Avana, R. R. B. Leakey et al., "Vegetative propagation of Prunus africana: effects of rooting medium, auxin concentrations and leaf area," Agroforestry Systems, vol. 54, no. 3, pp. 183-192, 2002.

[44] A. Harivel, R. Bellefontaine, and O. Boly, "Aptitude à la multiplication végétative de huit espèces forestières d'intérêt au Burkina Faso," Bois et Forêts des Tropiques, vol. 288, no. 2, pp. 39-50, 2006.

[45] Q. Meunier, R. Bellefontaine, and O. Monteuuis, "La multiplication végétative d'arbres et arbustes médicinaux au bénéfice des communautés rurales d'Ouganda," Bois et Forêts des Tropiques, vol. 295, no. 2, pp. 71-82, 2008.

[46] J. Kengue, Safou (Dacryodes edulis): Manuel du Vulgarisateur, University of Southampton, International Centre for Underutilised Crops (ICUC), Southampton, UK, 2003.

[47] Z. Tchoundjeu, A. C. Tsobeng, E. Asaah, and P. Anegbeh, "Domestication of Irvingia gabonensis (Aubry Lecompte) by air layering," Journal of Horticulture and Forestry, vol. 2, no. 7, pp. 171-179, 2010.

[48] J. C. Weber, C. S. Montes, A. Kalinganire, T. Abasse, and M. Larwanou, "Genetic variation and clines in growth and survival of Prosopis africana from Burkina Faso and Niger: comparing results and conclusions from a nursery test and a long-term field test in Niger," Euphytica, vol. 205, no. 3, pp. 809-821, 2015. 

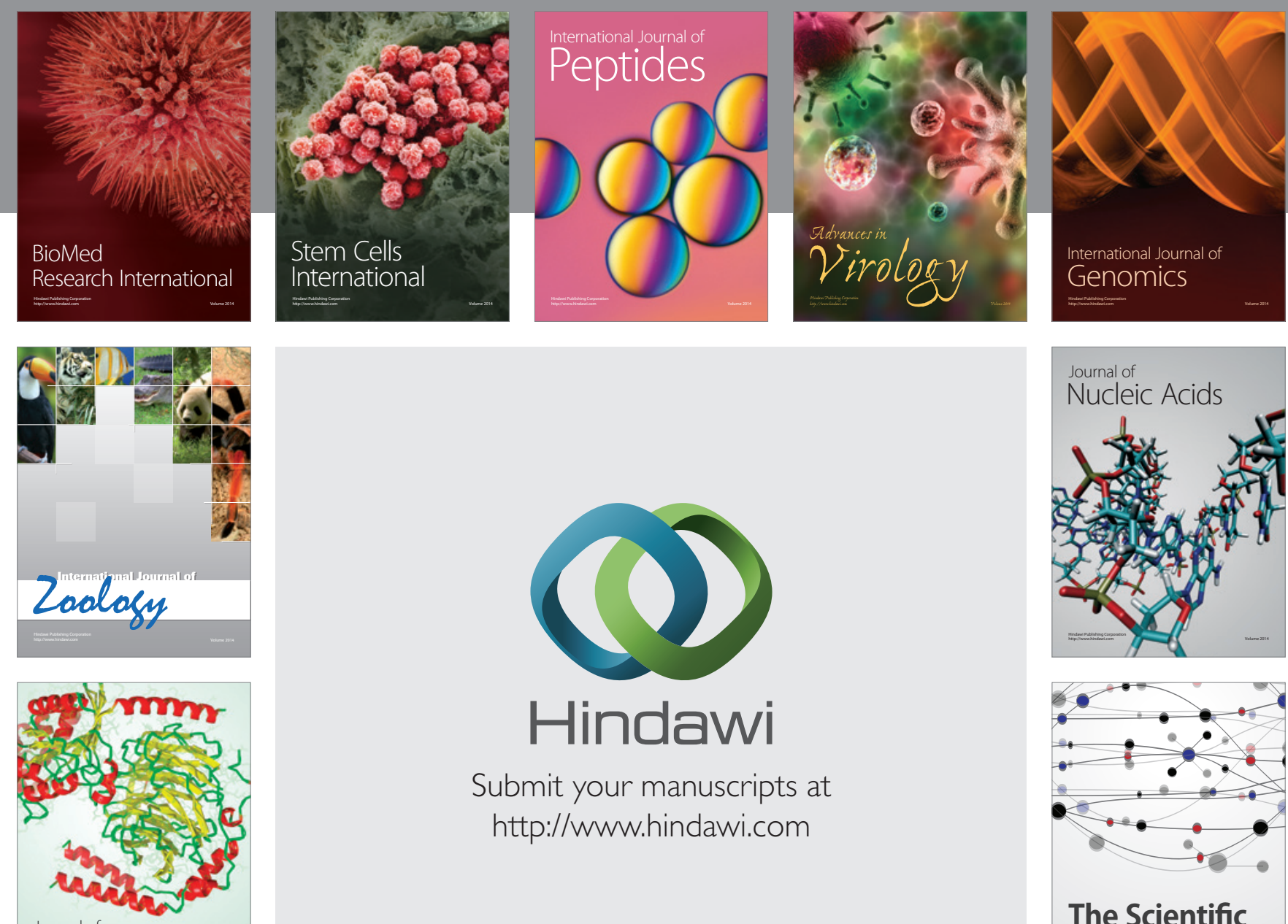

Submit your manuscripts at

http://www.hindawi.com

Journal of
Signal Transduction
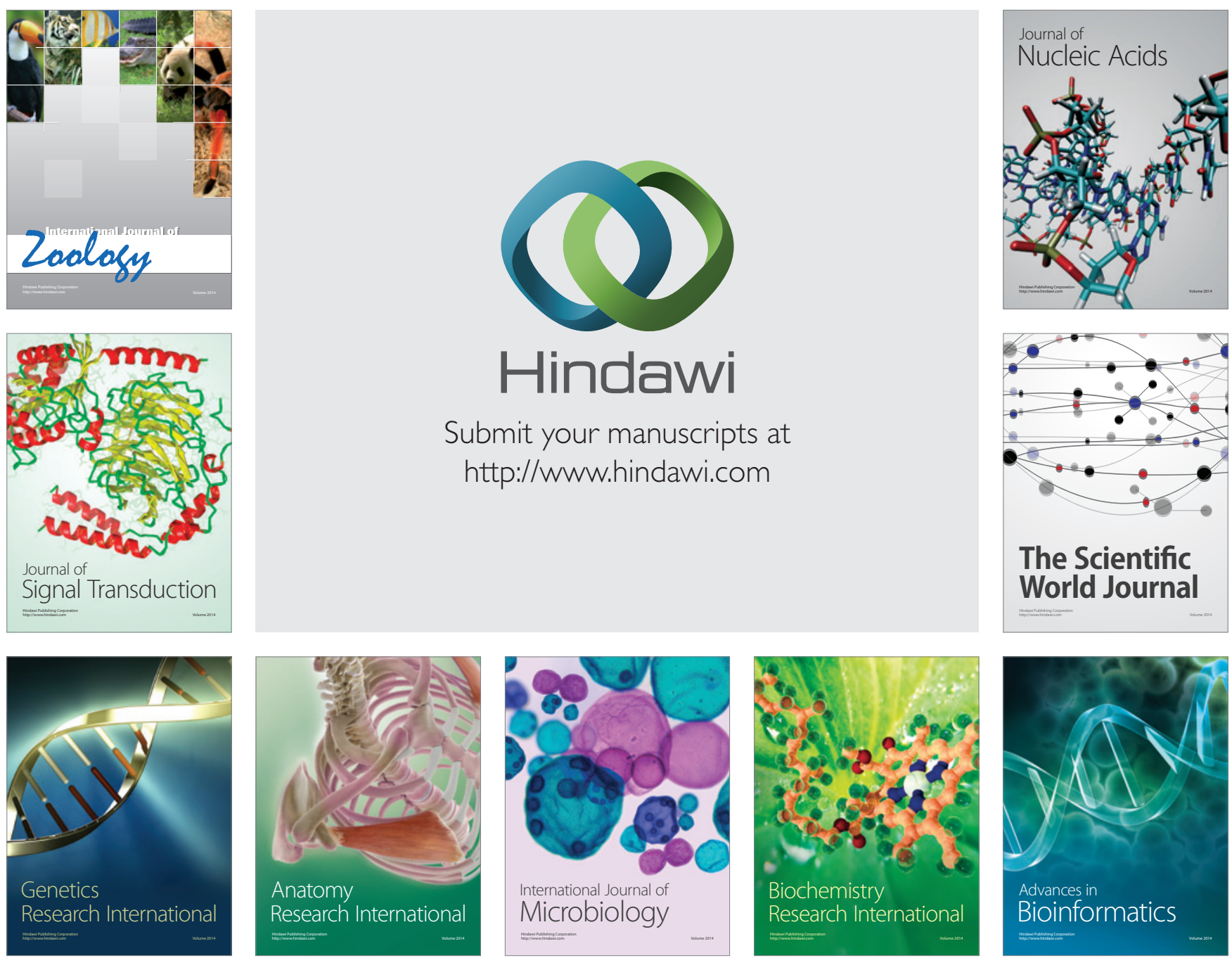

The Scientific World Journal
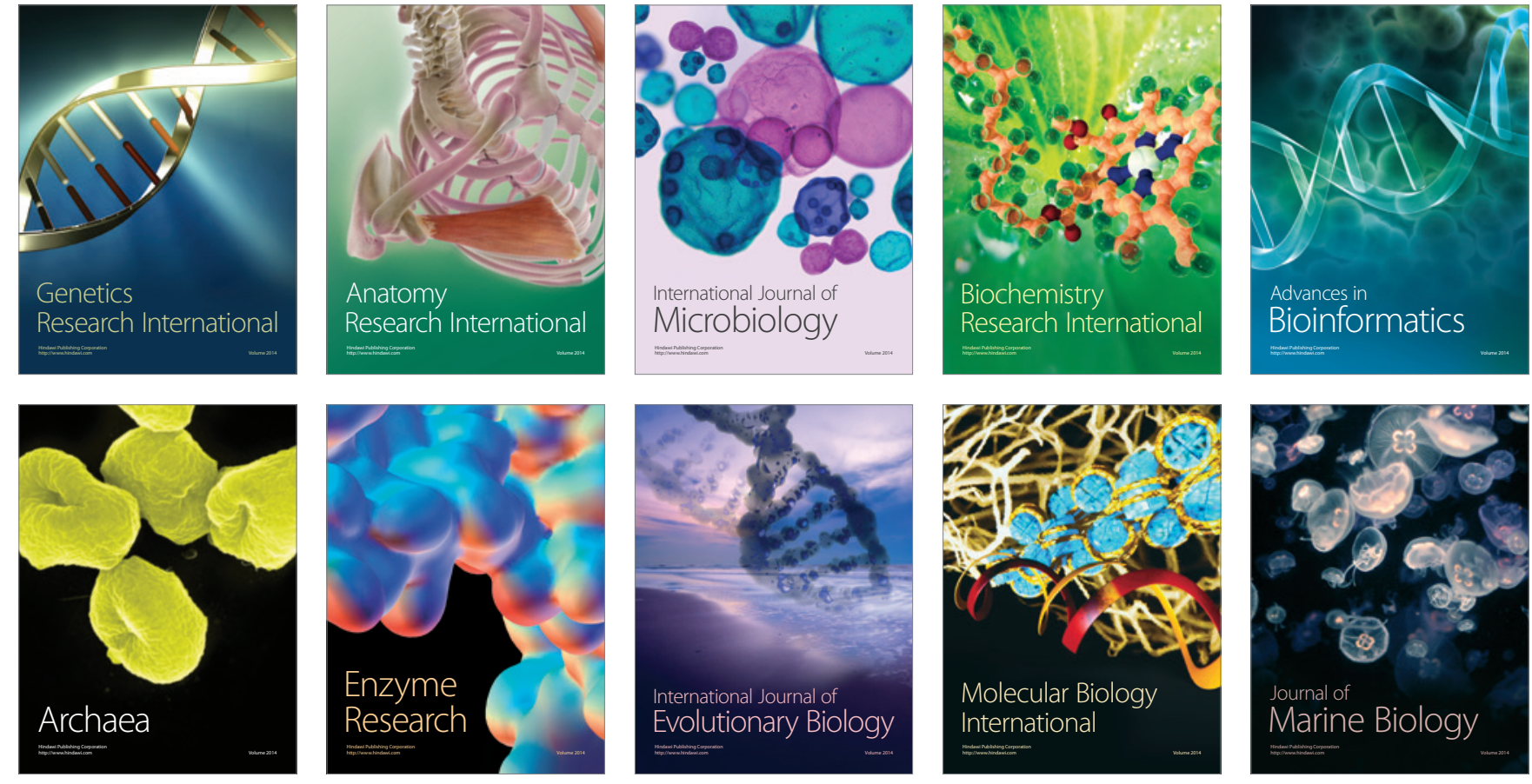